\title{
The Cultivation of Undergraduates with Applied Abilities in Four-year Program Applied Universities in China
}

\section{Li Zhitao}

School of English Language and Literature, Zhejiang International Studies University, Hangzhou, China

\section{Email address:}

liztli@163.com

\section{To cite this article:}

Li Zhitao. The Cultivation of Undergraduates with Applied Abilities in Four-year Program Applied Universities in China. Higher Education Research. Vol. 4, No. 2, 2019, pp. 36-41. doi: 10.11648/j.her.20190402.13

Received: April 17, 2019; Accepted: June 10, 2019; Published: June 25, 2019

\begin{abstract}
This paper explores how undergraduates with applied abilities can be cultivated. After a review of traditional educational concepts in research-oriented universities, the paper qualitatively and quantitatively analyzes the backgrounds of the cultivation of undergraduates with applied abilities in applied universities. Based on the theory of Outcome-Based Education (OBE), the paper puts forward a new cultivation model of undergraduates with applied abilities. The new model emphasizes (1) The reconstruction of educational concept is of first importance;(2) An applied-ability-oriented curriculum must give special attention to the design of practical teaching system; and (3) The development of teachers' applied abilities can not be neglected. Six years practice of this new model of cultivation at the author's university proves that the comprehensive qualities, applied abilities, self-developmental abilities and international vision of the students have been obviously improved.
\end{abstract}

Keywords: Cultivation of Undergraduates with Applied Abilities, Outcome-Based Education (OBE), Reconstruction of Educational Concept, Design of a Curriculum, Development of Teachers' Applied Abilities

\section{Introduction}

The mission of undergraduate education is to enable "students to systematically master the basic theory and basic knowledge necessary for the respective discipline and specialty, master the basic skills, techniques and related know-how necessary for the respective specialty, and acquire initial capability for the practical work and research work of the respective specialty." [1] According to Gu Jianmin, a general undergraduate education is mainly designed to lead participants to a deeper understanding of a subject or group of subjects. Successful completion of undergraduate programs may or may not provide the participants with a labor-market-relevant qualification. [2] For a long time, all four-year program universities are longing for being upgraded as members of key universities such as "985","211"or "Double first class"universities. Therefore, the majority of the four-year program universities are trying to produce advanced manpower for leaders in the government, managers, researchers and technological experts in business sector. With the development of social economy, there has been strong demand for advanced manpower with applied abilities such as technological experts, and advanced manpower with applied abilities in tertiary industry. As a consequence, there was a time when users of undergraduates could not find the right personnel to work for them.

In recent years, with the rapid expansion of undergraduate education, it is viewed that four-year program universities in China can be divided into 2 levels and 2 types. The 2 levels are key universities and four-year program applied universities. The 2 types are research-oriented universities and application-oriented universities. The key universities are supposed to be research-oriented while general universities are application-oriented. The four-year program applied universities shall shoulder the immense responsibilities of producing advanced manpower with applied abilities. How can manpower with applied abilities be cultivated in applied universities? This paper tries to answer this question.

\section{Reconstruction of Educational Concepts in Applied Universities in China}

\subsection{Educational Concepts of Universities Before 2000}

It is globally acknowledged that talent cultivation is the 
first function of a university. In terms of the cultivation of talents, different educational concepts will make great differences in the outcome of manpower. Before the year 2000, universities in China were supposed to be research-oriented. Therefore, they generally had more theoretical courses, less experiment courses, more courses within the specialty, less courses outside the specialty. Such universities had problems of overspecialization, a narrow focus on specialty education with little attention on general education, strong boundaries between specialties, little cross-disciplinary and inter-disciplinary efforts, over-emphasis on theory and foundation knowledge, and little attention on the application of theories, knowledge, practical capabilities and skills. In terms of models of teaching, teacher-centered teaching model dominated the classroom. Teachers put much attention to the passing of disciplinary knowledge to the students and paid little attention to the applied abilities that students would get.

\subsection{Reconstruction of Educational Concept in Applied Universities}

\subsubsection{Theoretical Background: Outcome-Based Education $(O B E)$}

Outcome-Based Education (OBE) is an approach of curriculum design and teaching that focuses on what students should be able to do (attained) at the end of course/programme. Carroll (1963), Bloom (1968), Spady (1988, 1994), among others have contributed to the significant development of OBE. According to Spady (1994), Outcome-based education (OBE) is an educational theory that bases each part of an educational system around goals (outcomes). By the end of the educational experience, each student should have achieved the goal. There is no single specified style of teaching or assessment in OBE; instead, classes, opportunities, and assessments should all help students achieve the specified outcomes. [3] OBE can be a very good rationale for the cultivation of undergraduates with applied abilities.

\subsubsection{The Aims of Cultivation}

A person is educated for many reasons, one of which is to serve for his country and get a job as means of earning a living. With the change of industrial structure, the concept of talent is also under the process of change. "Talents with inter-disciplinary abilities"and "Talents with applied abilities" have become the key words of talents. Talents are more required to have comprehensive qualities and enjoy creative abilities. The past specialty education can no longer adapt to the demands of social economy. It will not be very difficult to realize that the new concept of talent is to create a new model of talent cultivation, construct an inter-disciplinary and applied-ability-oriented teaching and learning system so as to implement an inter-disciplinary cultivation of talents with applied abilities.

Any university must take it into serious consideration that what kind of undergraduates it needs to cultivate. It should be very clear for a university to know that it is to cultivate research-oriented talents or applied-ability-oriented talents. It would be understandable that an applied university is to cultivate talents with applied abilities that possibly find jobs in business sectors such as companies and factories, in financial bodies such as banks and corporations of securities, to name just a few. If a university decides that it will cultivate talents with applied abilities, it should go further to spot what kind of applied abilities its talents should enjoy. Usually a university has many specialties or groups of specialties. Each specialty has its own aim of talent cultivation, or each group of specialties has its related aims of cultivation. So it is not easy to describe all the applied abilities that a university would like to cultivate for its talents. However, examples can illustrate this. Take the specialty of Business English talents needing what kind of applied abilities as an example. In order to deeply know what kind of applied abilities Business English talents should have that are required by foreign-involved organizations, an investigation was carried out in 186 foreign-involved organizations by means of questionnaires. [4] This investigation was based on 10 districts of Zhejiang province, a typical export-oriented province, in which there are 35,000 export-oriented enterprises. This investigation was carried out by choosing export-oriented enterprises at random and by way of face to face questions and answers. The investigation shows that export-oriented enterprises have their value orientations for foreign-involved talents with applied abilities, which have some implications for the orientation of training foreign-involved talents of Business English.

i. Export-oriented enterprises have a broad range of demands for inter-disciplinary talents with applied abilities. When answering this question"Which of the following disciplines that are recombined can properly meet your demand?", the results are as follows.

Foreign language + e-commerce, $21.32 \%$;

Foreign language + marketing, 20.31\%;

Foreign language + computer, $19.14 \%$;

Foreign language + international trade, $18.18 \%$;

Foreign language + tourism and hotel management, $14.83 \%$;

Foreign language + law, $5.74 \%$.

ii. What mode of cultivation can a university adopt to cultivate talents with applied abilities? When answering this question, the answers are:

Domestic specialty learning + abroad job post internship $30.96 \%$;

Campus specialty learning + outside campus job post internship 26.53\%;

Domestic specialty learning + abroad specialty extension 20.64\%;

Campus specialty learning + professional qualification certificate $14.00 \%$;

Campus specialty learning $7.37 \%$.

These findings show that (1) Specialty education is not enough for foreign-involved Business English talents with applied abilities. Moreover, they need inter-disciplinary education.(2) foreign-involved Business English talents with 
applied abilities must be trained not only domestically but also abroad, not only on campus but also in job post, not only specialty learning but also extension learning, not only specialty learning but also professional learning. By inference, we can safely say that all disciplinary talents with applied abilities must be cultivated by the combination mode of theory and practice, especially by emphasizing on the cultivation of practical abilities in job posts.

OBE emphasizes the outcomes of learning. The focus on outcomes creates a clear expectation of what needs to be accomplished by the end of the course. Students will understand what is expected of them and teachers will know what they need to teach during the course. [5] Butler (2004) holds that those designing and planning the curriculum are expected to work backwards once an outcome has been decided upon; they must determine what knowledge and skills will be required to reach the outcome. [6] Cultivating aims decide outcomes. This means that teachers should clearly know the cultivating aims of each course and each discipline.

\subsubsection{Three Important Educational Concepts Under the Theory of $\mathrm{OBE}$}

i. Student-centered concept.

Student-centered concept is a core concept of OBE theory in the design, implementation and evaluation of teaching, which embodies the core value of talent cultivation of OBE.

The basic questions of teaching are "What to teach?", "How to teach?" and "What about the outcomes of teaching?" while the basic questions of learning are "What to learn?", "How to learn?" "What about the outcomes of learning?" If the teaching contents depend mainly on the learning contents, the teaching method depends mainly on the learning method, and the teaching evaluation depends mainly on the learning outcome, such a concept is student centered, or vice versa. Therefore, it is advocated that students like to learn, know how to learn and get learned.

ii. Backwards designing and planning.

Backwards designing and planning refers to an anti-direction designing and planning. Usually designing and planning begin from constructing curriculum system and then decide the right method to reach the aims of the courses. The designing of curriculum system is discipline-oriented. To the opposite, backwards designing and planning begin from the social demands. The social demands of talents decide on the aims of cultivation, the aims of cultivation decides on requirements of graduation, then the requirements of graduation decide on the curriculum system. This kind of designing and planning can actively meet the demands of society and economy.

iii. Continuous Improvement.

Continuous improvement is a core concept that OBE follows in the evaluation of teaching and learning. OBE evaluation values diagnosis and improvement functions which are neglected by traditional evaluation. OBE evaluation is process evaluation. It pays attention to dynamic evaluation of the whole process of teaching and learning.
During the process of evaluation of the process of teaching and learning, teachers can get information of the problems of teaching and learning, thus they can make improvements continuously.

Applied universities are supposed to cultivate talents with applied abilities, emphasizing the cultivation of practical skills and abilities. OBE is meant to be a student-centered learning model. OBE theory outbreaks the traditional educational concept of teacher-centered model of teaching and learning, emphasizing the values of dominant role of the students. Student involvement in the classroom is a key part of OBE. Students are expected to do their own learning so that they gain a full understanding of the material. Increased student involvement allows students to feel responsible for their own learning, and they should learn more through this individual learning. [7] Teachers are meant to guide and help the students understand the material in any way necessary, study guides, and group work are some of the methods instructors can use to facilitate students learning. The role of the teachers adapts into instructor, trainer, facilitator, and/or mentor based on the outcomes targeted. It points out that the target of course teaching and learning is to get corresponding abilities and all the teaching activities and teaching methods are for this very target and purpose. [8] Davis (2003) puts: "In OBE, product defines process." "OBE can be summed up as results-oriented thinking and is the opposite of input-based education where the emphasis is on the educational process and where we are happy to accept whatever is the result." [9]

Chen Shuibin and Yin Ming (2016) made a contrastive experiment between input-based education and outcome-based education about pre-class learning interest, teaching method, classroom learning behavior and the learning effects. [10] Their research found that input-based education and outcome-based education would have significantly different influences on them. Moreover, OBE has greater influence on classroom learning behavior and learning effects than input-based teaching mode.

\section{Some Important Measures for Cultivation of Talents with Applied Abilities}

For the cultivation of talents with applied abilities, it is necessary for applied universities to set up a demand-oriented educational concept, insist on the cultivating model based on the background of job posts, establish a new mechanism of cultivation with the cooperation of enterprises.

Talent cultivation is a system. It involves many subsystems such as system of teaching curriculum (including practical teaching and internship), system of teacher development, system of teaching quality control and evaluation, etc.

\subsection{The Design of Curriculum}

In order to cultivate talents with applied abilities who will enjoy popularity in the economical society, following the "student development centered" educational concept, 
construct a curriculum of theoretical courses and practical courses that are properly adjusted to meet the demands of social and economical development. Davis (2003) puts "OBE is an approach to education in which decisions about the curriculum are driven by the exit learning outcomes that the students should display at the end of the course." [9] What courses should be included in the teaching curriculum?

\subsubsection{The Theoretical Courses}

Generally speaking, the theoretical courses of a discipline are made up of the basic courses of a discipline, the core courses of a discipline and the extension courses of the discipline. The basic courses of a discipline are designed for students to grasp the basic knowledge of a discipline. The core courses of a discipline are intended for students to get the core abilities of a discipline. The extension courses of the discipline are designed for students to have more choice of courses relevant to the discipline. This kind of extension courses could be designed according to different modules, each of which has a clear orientation of talent cultivation. It is encouraged that universities will work together with line of trade (companies) to have the modules designed. The theoretical courses must be designed according to OBE. That is to say, the theoretical courses will be designed to help to lay a solid foundation for students to get their applied abilities in the discipline that are required in the future social and economical needs.

\subsubsection{The Practical Courses}

Li Zhiyi (2018) points out that the essence of OBE is to cultivate talents according to demand. [11] Here demand refers to the individual, social and economical demand. Therefore, the practical courses should give prominence to the training of applied abilities and should develop "student's self-developmental ability" as its ultimate objective. [12] According to Outcome-Based Education (OBE), different courses should have their respective corresponding outcomes, which should be closely related to their respective job practices. In this way, students can skillfully grasp the applied abilities used in the job.

The practical teaching is an important part of university education and an extension of theoretical teaching as well. The quality of practical teaching is closely related to students "use hands" ability or ability to solve practical problems. Namely, practical teaching plays a critical role in the cultivation of talents with applied abilities. For example, such disciplines as international economy and trade, accounting and e-commerce are of strong practicability and applicability. Therefore, practical teaching exerts a great influence in the cultivation of students' skills and applied abilities.

In addition to basic knowledge and theoretical knowledge of a discipline, students are also expected to grasp strong applied abilities and problem-solving abilities. If students have grasped basic knowledge and theoretical knowledge of a discipline, but have not gotten the applied abilities, it is not the aim of talent cultivation of an applied university. So it is certain that an applied university must emphasize the practical teaching and the cultivation of applied abilities.
What kind of applied abilities do students need to get? In order to cultivate students' applied abilities, it will not work if universities just depend on themselves. One good way is to get companies to work out the practical teaching model with the applied universities together. It needs the participation of companies (end-users of graduates from universities) to explore what kind of applied abilities to be cultivated. It is ideally expected that universities can design corresponding practical courses, the teaching methods of these practical courses and the evaluative methods of these practical courses according to such aims of applied abilities decided by both applied universities and companies. Only by this way the students" "use hands" abilities, the job-required abilities and relevant sustainable abilities can be cultivated.

\subsubsection{The Practical Teaching Model}

Different disciplines may have their respective characteristics, so the practical teaching models are different. Here take the practical teaching model of foreign-involved business disciplines for example.

i. Campus Simulation at different stages. It includes (1) classroom simulation practical teaching. Practical teaching is introduced into classroom by way of creating simulated environment, setting up case study, etc. In campus, classroom practical teaching is implemented according to the courses of applied discipline such as Business Translation, Business Negotiation, International Trade, Basic Accounting, Financial Management, Auditing and so on. For example, in the course of International Trade, students are required to make offers, do case studies of international trade and draft import and export documents. In the course of Intercultural communication, students are required to analyze the cultural elements that lead to the failure of some international companies in foreign countries and analyze non-cultural barriers in intercultural communication and intercultural team management. All these practical teaching must be part of the teaching plan of the course. (2) Comprehensive practical teaching. After learning a course, say, International Trade, students are required to practice all the processes of international trade: quotation, offer, negotiation, contract, delivery, insurance, customs clearance, payment, etc. This helps students to get real operating abilities for international trade. (3) The practical teaching of job-required abilities. At this stage, based on the classroom practical teaching of individual courses, design a practical teaching of applied abilities required for a certain job post such as assistant manager, office secretary in an international trade corporation.

ii. The practical teaching in companies. In order to cultivate high quality talents with applied abilities, different kinds of non-campus practical teaching are designed. (1) The practical teaching of social investigation. During vacations, students are organized to do social research about certain topics. This kind of social research can practice students' coordinating ability, communicative ability and ability to comprehensively use theoretical knowledge, which will lead to the improvement of their analytical and problem-solving 
abilities. (2) Graduation practice. Graduation practice covers almost all the contents related to the disciplinary courses. To guarantee the quality of graduation practice, employees from companies are going to be tutors to guide graduation practice. By having graduation practice in companies, students are expected to improve their comprehensive abilities, especially their applied abilities. (3) Job post practice as a form of graduation practice. Companies may offer job post practice to some excellent students. A student can work as an employee of a company under the guidance of a mentor in the company. The student gets paid. In this way, the student can get practiced in his applied abilities.

iii. The practical teaching in foreign countries. For undergraduates of some disciplines, it is necessary to have abroad job post internship in enterprises and have abroad specialty extension. Undergraduates can benefit a lot from such practices. In surface level, abroad job post internship and abroad specialty extension can help students to enlarge global vision, experience intercultural communication, enrich international experience, enforce international awareness, to name just a few. In deep level, abroad job post internship and abroad specialty extension can help students to improve individual disciplinary abilities (especially applied abilities), enlarge specialty-related knowledge, upgrade international accomplishments and international competitiveness. In deeper level, abroad job post internship and abroad specialty extension can help students get the abilities of participating relevant international affairs, solving relevant international problems, tackling relevant international challenges and so on.

\subsection{The Improvement of Teachers}

Currently, most teachers are not well prepared for cultivating talents with applied abilities for two reasons: firstly, most applied universities require that their new teachers must have a doctorate degree. Only research-oriented universities can cultivate $\mathrm{PhD}$ students. Such new teachers usually do not have a working experience in companies. Secondly, some of the current teachers in applied universities do not have a working experience in companies either, and they are also used to the teaching of research-oriented students.

Applied universities are in urgent need of teachers with applied abilities because teachers are the fundamental guarantors for talent cultivation. Good masters can produce good apprentices. Literature shows that there is not much research on the development of teachers with applied abilities. Our research and practice are as follows:

Firstly, teachers must adjust their teaching concept in applied-ability-centered classroom teaching. Based on the full introduction of Outcomes-based Education (OBE), teachers are required to not only focus on the teaching of systematic knowledge of the discipline, but also focus on the cultivation of students' applied abilities. Teachers need to open new courses that are beneficial to the cultivation of applied abilities. They need to teamwork with other teachers (teachers of the same discipline or other discipline, teachers from companies). In the past, teachers used to delivering lessons that are theory- based and knowledge-based and then go home to do research and have papers published. The cultivation of applied abilities had no important relations with them. Now the teachers face the challenge of the focus shift from knowledge-centered classroom teaching to applied-ability-centered classroom teaching.

Secondly, teachers need to be sent out to get familiar with the market. Although teachers can get to know the market by the way of different project cooperation between companies and universities, this is not at great depth of experience. If universities want to cultivate students with applied abilities that are closely related to the market, first the teachers need to be closely related to the market themselves. For example, if a university needs to open some courses that are applied-ability-centered, send teachers to the market to learn these courses, then transform these courses to be courses of the university. In this way, the market experience can be transformed to classroom teaching and students can learn applied ability. A university can usually adopt the following methods to improve its teachers' applied ability. (1) Teachers can be sent to the base of practical teaching (usually companies) to learn applied abilities. According to teaching schedule, it is necessary for relevant teachers to participate in the practical teaching in the base of practical teaching so as to improve their applied abilities. (2) Teachers are encouraged to do research on company projects, investigations about company business, and to participate in the management of companies. On the one hand, teachers can pass their theoretical knowledge to companies, which may better their market competition; on the other hand, teachers can also learn and improve their applied abilities.

Thirdly, company managers can be invited to do part-time teacher job in applied universities. They know the market very well. Therefore, universities can invite them to help university teachers to make out curriculum, especially the practical teaching courses, to give help to train university teachers to get applied abilities, to deliver applied-ability-centered courses for students, to give lectures for both students and teachers, and so on.

\section{Conclusion}

This paper discusses the research on the cultivation of talents with applied abilities. An applied university is different from a research-oriented university. The reconstruction of teaching concept is of first importance. To train students with applied abilities, the teacher-centered and input teaching methodology should not be advocated. It is hoped that the student-centered and outcome-based methodology be implemented. An applied university should construct its curriculum according to OBE and give special attention to the practical courses, which is helpful for the cultivation of applied abilities. In order to nurture students with applied abilities, a workable curriculum is necessary. Besides theoretical courses that are fundamental, it is also very important to design proper practical teaching system 
that will certainly benefit the improvement of students' applied abilities. A guide book can tell a person how to ride a bike but can not give him the riding skills if he does not practise enough. Last but not least, teachers should also be developed to be with applied abilities. Teachers are the guarantors of the cultivation of talents with applied abilities. If teachers are without applied abilities themselves, they are not qualified to teach practical courses that are intended to cultivate applied abilities. The six-year practice of this cultivation model resulted in good improvement of students' applied abilities.

\section{References}

[1] NPC (1998). Laws and Regulations: Higher Education Law of the People's Republic of China (Article 16). Retrieved July 16 , 2008 from http://www.moe.edu.cn/(English version).

[2] Gu Jianmin (2009). Higher Education in China. Hangzhou: Zhejiang University Press.

[3] Spady, William (1994). Outcome-Based Education: Critical Issues and Answers (PDF). Arlington Virginia: American Association of School Administrators. ISBN 0876521839. Retrieved 31 October 2014.

[4] Du Tiansun (2010). The Cultivation of Foreign-involved interdisciplinary talents with applying abilities under the background of transformation and upgrading. Higher Education in China, 21, 34-36

[5] Tam, Maureen (2014). "Outcomes-based approach to quality assessment and curriculum improvement in higher education". Quality Assurance In Education. 22 (2): 158-168.

[6] Butler, Mollie (2004). Outcomes Based/ Outcomes Focused

[7] Education Overview.

https://en.wikipedia.org/wiki/Outcome-based_education

[8] Malan, SPT (2000). The "New Paradigm" of Outcomes-based Education in Perspective (PDF). Tydskrif vir Gesinsekologie en Verbruikerswetenskappe. 28.

[9] Davis (2003). quoated from "OBE IMPLEMENTATION GUIDEBOOK”.https://docplayer.net/10865667-Obe-impleme ntation-guidebook.html.

[10] Chen Shuibin, Yin Ming (2016). Comparative Research on the Effects of Outcome-based Education and Input-based Education in A Professional Course. Journal of Guangdong Professional College of Water Resources and Hydropower, 2, 39-42.

[11] Li Zhiyi (2018). Reform of Cultivating System for Talents with Applied Abilities. China University Education, 3: 57-61.

[12] Li Zhitao (2012). The Innovation and Practice of Practical Teaching Model in Applied Foreign-involved Business Majors. Social Science Review, 27 (9): 188-189. 